\title{
The Gastroprotective Activity of Ethanol Extract of Curcuma domestica Val. on Mice Induced Ethanol - HCl
}

\author{
Fitri Rahmania Farikha, Moch. Saiful Bachri* \\ Faculty of Pharmacy, Ahmad Dahlan University, Yogyakarta, Indonesia
}

\begin{abstract}
Curcuma domestica Val. (CD) is one of plant used as traditional medicine in around the world. One of the benefit of CD is to treat peptic ulcers. The aim of preset study to prove that the ethanol extract of $C D$ has gastroprotective activity. This study used 25 male mice were divided into 5 groups. Group I as a control group were given suspension of $0.5 \% \mathrm{Na}-\mathrm{CMC}$, groups II, III, and IV were each given ethanol extract of CD suspense with $0.5 \% \mathrm{Na}-\mathrm{CMC}$ at a dose of $50 \mathrm{mg} / \mathrm{kg} ; 100 \mathrm{mg} / \mathrm{kg} ; 200 \mathrm{mg} / \mathrm{kg}$ respectively, and group $\mathrm{V}$ was given ranitidine $10 \mathrm{mg} / \mathrm{kg}$. All groups were treated orally for 6 days, then fasted for 24 hours, on the seventh day all mice induced $3 \mathrm{M} \mathrm{HCl}$ - ethanol $60 \%$ (I:I) $0.2 \mathrm{~mL} / 25 \mathrm{gBW}$. One hour later, mice were sacrificed by cervical dislocation, then dissected and taken gastric. Then performed an ulcer scoring and the curative ratio is calculated later in the histopathologic test. Data were analyzed using Kolmogorov-Smirnov test and the Levene test and ANOVA followed by LSD test level of $95 \%$. The results showed there was no significant difference between the control with dose $50 \mathrm{mg} / \mathrm{kgBW}(p>0.05)$ and showed significant difference between control with dose $100 \mathrm{mg} / \mathrm{kgBW}(p<0.05)$, dose of 200 $\mathrm{mg} / \mathrm{kgBW}(p<0,05)$, and ranitidine $10 \mathrm{mg} / \mathrm{kgBW}(p<0.05)$. Curative ratio percentage dose of $100 \mathrm{mg} / \mathrm{kgBW} ; 200 \mathrm{mg} / \mathrm{kgBW}$, and ranitidine are $38.89 \%, 61.1 \mathrm{l} \%$ and $66.67 \%$ respectively. The conclusion of this research, the ethanol extract of Curcuma domestica $\mathrm{Val}$ at the dose $100 \mathrm{mg} / \mathrm{kgBW}$ and $200 \mathrm{mg} / \mathrm{kgBW}$ showed have gastroprotective activity.
\end{abstract}

Keywords: Gastroprotective, Curcuma domestica Val., ethanol-HCl, Gastric ulcer

\section{INTRODUCTION}

Currently, peptic ulcers become a disease that affects many people and may caused of death. Gastric ulcer is one form of peptic ulcer characterized by the mucosal layer damage. The imbalance between aggressive and protective factors is the onset of peptic ulcers. Hyper secretion of gastric acid as a factor in aggressive is a pathological condition that occurs due to secretion of $\mathrm{HCl}$ uncontrolled from the parietal cells of the gastric mucosa, while damage to the mucus layer that serves as a protective factor on the surface of the gastric mucosa can worsen the situation (Saputri, et al., 2008).

Many conditions cause an imbalance of both factors. Excessive reaction to certain foods, beverages containing caffeine and alcohol, stress, stimulation of the parasympathetic and histamine stimulates parietal cells to produce $\mathrm{HCl}$. The use of drugs such as non-steroidal anti-inflammatory
(NSAID) is closely related to the occurrence of gastric bleeding through the irritation of the epithelial cells directly and digestive tract mucosal prostaglandin synthesis. The existence of Helicobacter pylori can remove toxins that disrupt the mucosal defenses and increase the release of gastrin (Saputri, et al., 2008).

Curcuma domestica (CD) or Curcuma longa or turmeric, has long been used as traditional medicine for example to resolve inflammation, diarrhea, abdominal pain, jaundice, gastritis and peptic ulcers. From the research results, CD extract shows antiinflammatory, antibacterial, antioxidant, antiulcer, and gastroprotective (Atmaja, 2008). Curcumin has yellow phenolic groups derived from the rhizome of C. longa. In the crude extract of C. longa rhizomes are 70-76\% curcumin, 16\% desmethoxycurcumin and 8\% bisdemethoxycurcumin (Kohli, et al., 2005).

$\overline{\text { *Corresponding author e-mail: msaifulbachri@yahoo.co.id }}$ 


\section{MATERIALS AND METHOD}

\section{Extraction of CD}

$\mathrm{CD}$ rhizomes are cleaned peeled, chopped into small pieces, dried in an oven at a temperature of $50^{\circ} \mathrm{C}$ for 24 hours, and then blended to obtain the powder. Ethanol extract of $\mathrm{CD}$ was made by maceration. $\mathrm{CD}$ has added $96 \%$ ethanol and stirred with an electric mixer at a scale speed of $70 \mathrm{rpm}$ for 3 hours and allowed to stand for 24 hours, sealed with plastic then filtered and evaporated over a water bath with the temperature of $60^{\circ} \mathrm{C}$.

\section{Treatment to Animal Testing}

The experiment was performed according to the method of Mizui and Douteuchi (1983), with some modifications. Before the experimental, the mice were maintained under the constant condition and had free access to rodent food and tap water and keep under $12 \mathrm{~h}$ light/dark. After acclimatization to the laboratory conditions for 1 week, 25 male mice were divided into five groups. Each group consisted five mices. The body weight of mice 20-30 grams, 6-8 weeks aged. Each groups received one of the following treatments for 6 days. Control group were administered vehicle $0.5 \%$ Na-CMC; ethanol extract of CD dose 50;100; $200 \mathrm{mg} / \mathrm{kg}$ groups, and ranitidine dose $10 \mathrm{mg} / \mathrm{kg}$. Each group was treated for 6 days at relatively the same hour. Then fasting for 24 hours, on the seventh day all mice induced $3 \mathrm{M} \mathrm{HCl}$ - ethanol
$60 \%$ (1: 1) are orally $0.2 \mathrm{~mL} / 25$ grams mice to induce the gastric ulcer. One hour later, mice were sacrificed by cervical dislocation, then dissected and taken gastric. Gastric was cleaned with $0.9 \% \mathrm{NaCl}$ physiological fluid to removed gastric content, and then put in a 5\% formalin solution for 10 minutes. Then performed an ulcer scoring (Table 1) and curative ratio and test.

Curative Ratio Calculations (Darbar, 2010)

Curative Ratio $=$

ulcus score of control - ulcus score of sample x $100 \%$ ulcus score of control

The Data were analyzed using Kolmogorov-Smirnov test and the Levene test and ANOVA followed by LSD test level of $95 \%$.

\section{Histopathology of Mice Gastric}

Mice were sacrificed and gastric were separated, washed repeatedly with normal saline and stored in $10 \%$ formalin until further use . The gastric tissues processed by passing through multiple changes of dehydrating using ethanol and clearing solvent, xylene. After processing, the specimens were embedded in paraffin and $5 \mu \mathrm{m}$ thick paraffin sections were sliced and stained with hematoxylin and eosin (H\&E), tested under binocular light microscope and photographs were taken.

Table I. Scoring severity ulcers with modification (Manaiyan, et al., 2008)

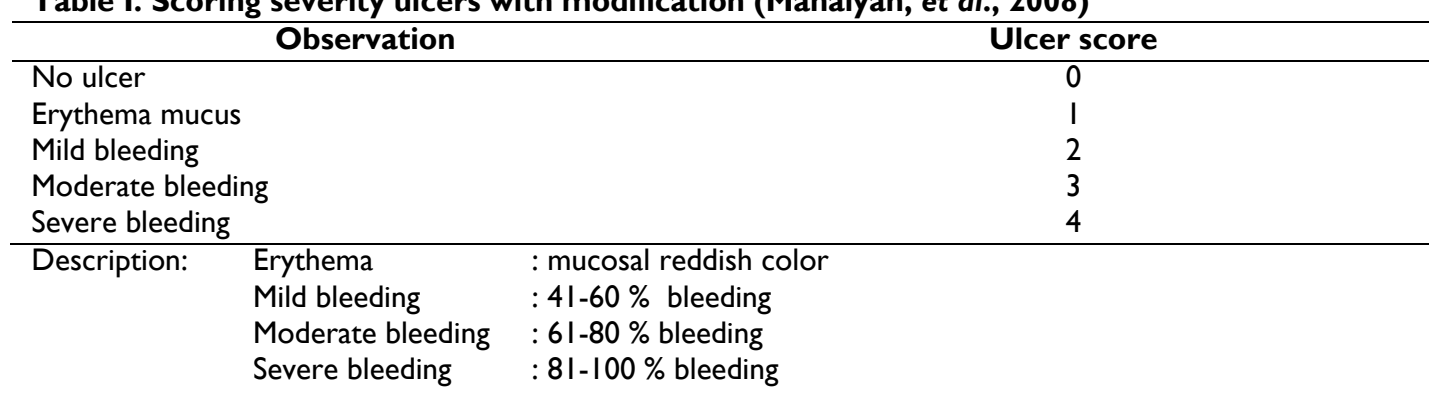




\section{RESULTS AND DISCUSSION}

\section{Gastro Protector Activity}

Table 2 showed the ethanol extract of $\mathrm{CD}$ dose $50 \mathrm{mg} / \mathrm{kg}$ significant not different with control group, while dose 100 and $200 \mathrm{mg} / \mathrm{kg}$ of ethanol extract of CD obviously different significant compare with control group.

The result of this study clearly demonstrate that oral administration of ethanol extract of $\mathrm{CD}$ induced ethanol-HCl significantly reduced the severity of gastric ulcers in mice also showed dose dependent in gastroprotector activity. The gastroprotective activity of $C D$ lower than ranitidine. The imbalance between aggressive and protective factor is the onset of peptic ulcers. Hyper secretion of gastric acid as a factor in aggressive is a pathological condition that occurs due to secretion of $\mathrm{HCl}$ uncontrolled from the parietal cells of the gastric mucosa, while damage to the mucus layer that serves as a protective factor on the surface of the gastric mucosa can worsen the situation (Saputri, et al., 2008).

The extract ethanol of CD dose $50 \mathrm{mg} / \mathrm{kg}$ showed significant not different with control group, while dose 100 and $200 \mathrm{mg} / \mathrm{kg}$ of ethanol extract of $\mathrm{CD}$ obviously different significant compare with control group.

$\mathrm{HCl}$ caused severe damage to the gastric mucosa, while ethanol produces lesions necrosis with action necrosis directly reducing factors such defensive secretion of bicarbonate and mucus production (Alrashdi, et al., 2012), and increased acid secretion (Lima, et al., 2009). Ranitidine is an $\mathrm{H} 2$ receptor antagonist role in reducing gastric acid secretion by inhibiting the binding of histamine $\mathrm{H} 2$ receptor selectively (Aziz, 2002). CD extract showed selective H2R antagonist effects and competitive on the mechanism for the reduction of gastric ulcers (Kim, et al., 2005). Curcumin is one of the best-known examples of cytoprotector. The cytoprotective effect is due to its ability to maintain the network and cellular integrity in the face of mucosal damage by maintaining prostaglandin secretion, inhibits acid secretion, stimulate mucus and bicarbonate secretion and increases cell turnover and mucosal blood flow (Mohamed, 2010).

\section{Histopathology Gastric Mice}

Based on the result analysis of histopathological images (Fig. 1-5), the control group there were gastritis and hemorrhage, also the dose groups of $50 \mathrm{mg} / \mathrm{kgBW}$ are gastritis, hemorrhage, the dose group of $100 \mathrm{mg} / \mathrm{kgBW}$ are gastritis, the dose group of $200 \mathrm{mg} / \mathrm{kgBW}$ are gastritis and hemorrhage, whereas in the ranitidine group there were gastritis and edema. Result didn't show difference all the group. The weakness in the histopathological test sample is used only a fraction of its organs, so that can't be observed from the whole gastric mucosa.

Table 2. The average score ulcers \pm SD and curative ratio in male mice induced by ethanol- $\mathrm{HCl}$ each group.

\begin{tabular}{cccc}
\hline Groups & Dose $\mathbf{( m g / k g )}$ & Ulcus Score & $\begin{array}{c}\text { Curative Ratio } \\
\text { (\%) }\end{array}$ \\
\hline Control & & & - \\
Ethanol extract of CD & 50 & $3.6 \pm 0.55$ & 16.67 \\
& 100 & $3.0 \pm 0.71$ & 38.89 \\
Ranitidine & 200 & $2.2 \pm 0.45^{*}$ & 61.11 \\
note $: * p<0,05$, different significant compare control group & $1.4 \pm 0.89^{*}$ & 66.67 \\
\hline
\end{tabular}




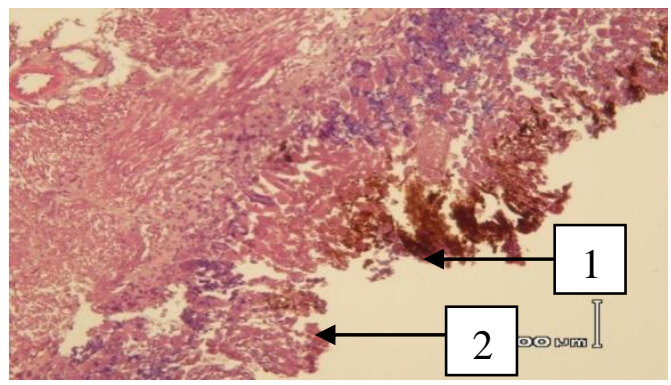

Figure I. Histopathologic images gastric ulcer control group of mice induced with ethanol-HCl $\mathrm{HE}$ staining, magnification $400 X$. appearance (I) hemorrhage, (2) gastritis.

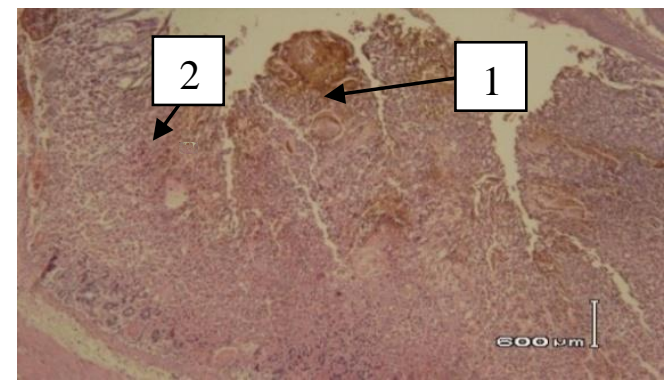

Figure 2. Histopathologic images gastric ulcer ethanol extract if CD group dose $50 \mathrm{mg} / \mathrm{kgBW}$ induced ethanol-HCl with $\mathrm{HE}$ staining, magnification $400 \mathrm{X}$. appearance (I) hemorrhage, (2) gastritis.

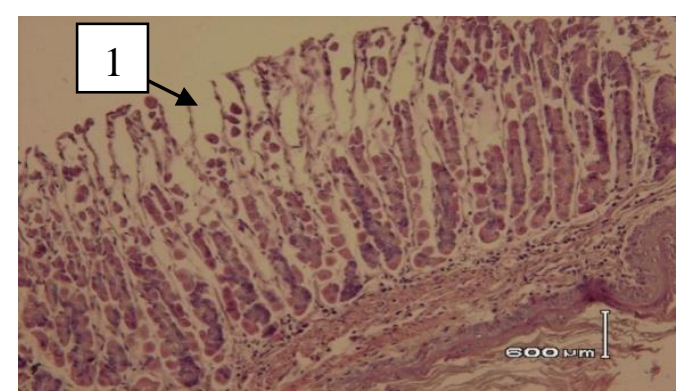

Figure 3. Histopathologic images gastric ulcer ethanol extract if CD group dose $100 \mathrm{mg} / \mathrm{kgBW}$ induced ethanol- $\mathrm{HCl}$ with $\mathrm{HE}$ staining, magnification 400X. appearance (I) gastritis.

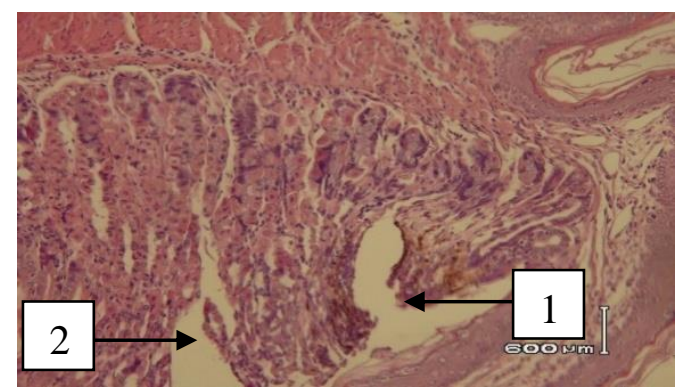

Figure 4. Histopathologic images gastric ulcer ethanol extract if CD group dose $200 \mathrm{mg} / \mathrm{kgBW}$ induced ethanol-HCl with $\mathrm{HE}$ staining, magnification 400X. appearance (1) hemorrhage, (2) gastritis. 


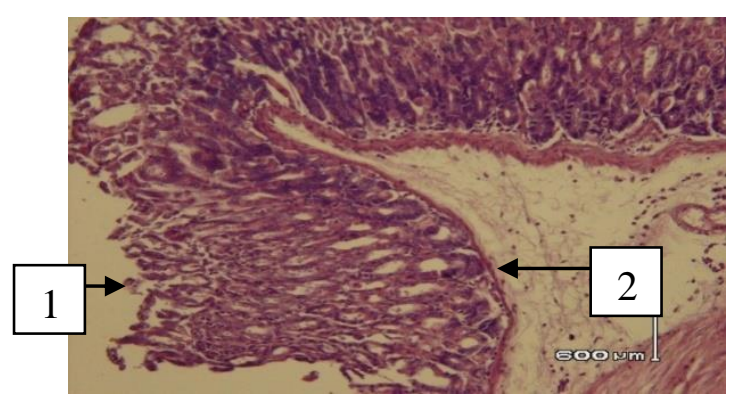

Figure 5. Histopathologic images peptic ulcers ranitidine group dose $10 \mathrm{mg} / \mathrm{kgBW}$ induced ethanol$\mathrm{HCl}$ with $\mathrm{HE}$ staining, magnification $400 \mathrm{X}$. appearance (I) gastritis, (2) edema.

Based on macroscopic qualitative observations on the score ulcers and curative ratio, showed that the ethanol extract of Curcuma domestica at $100 \mathrm{mg} / \mathrm{kgBW}$ and 200 $\mathrm{mg} / \mathrm{kgBW}$ possessed gastroprotective activity in ethanol- $\mathrm{HCl}$ induced mice.

\section{REFERENCE}

Alrashdi, A.S., Salama, S.M., Alkiyumi, S.S., Abdulla, M.A., Hadi, A.H., Abdelwahab, S.l., et al., 2012, Mechanisms of Gastroprotective Effects of Ethanolic Leaf Extract of Jasminum sambac against $\mathrm{HCl} /$ Ethanol-Induced GastricMucosal Injury in Rats, Evid. Based Complement Alternat. Med., 20 I 2(20I2),786426.

Atmaja, D. A., 2008, Pengaruh Ekstrak Kunyitt (Curcuma domestica) Terhadap Gambaran Mikroskopik Mukosa Lambung Mencit BALB/C yang Diberi Parasetamol, Essay, Fakultas Kedokteran Universitas Diponegoro, Semarang.

Aziz, N., 2002, Peran Antagonis Reseptor H-2 Dalam Pengobatan Ulkus Peptikum, Sari Pediatri, 3(4), 222-226.

Bloom and Fawcett, 2002, Buku Ajar Histologi, 12 Edition, Jakarta: EGC.

Darbar, S., 2010, Antiulcer Effect of Livina, a Herbal Formulation agains Ethanol Induced Acute Gastric Ulcer in Mice, Int. J. Pharm., 2(10), 93-100.

Kim, D.C., Kim, S.H., Choi, B.H., Baek, N.I., Kim, D., Kim, M.J., et al., 2005, Curcuma longa Extract Protects against Gastric Ulcers by Blocking $\mathrm{H} 2$ Histamine Receptors, Biol. Pharm. Bull., 28(I2), 2220-2224.

Kohli, K., Ali, J., Ansari, M.J. and Raheman, Z., 2005, Curcumin: A Natural Antiinflammatory Agent, Indian J. Pharmacol., 37(3), |4I-I47.

Lima, I.O., Costa, V.B.M., Matias, W.N., Costa, D.A.D., Silva, D.A.E., Agra, M.D.F., et al., 2009, Biological Activity of Herissantia crispa (L.) Brizicky, Braz. J. Pharm., I9(IB), 249-254.

Manaiyan, M., Ghannadi, A., Mahzouni, P., and Meibodi, M.N., 2008, Anti-ulcerogenic Effect of Ginger (rhizome of Zingiber officinale Roscoe) Hydroalcoholic Extract on Acetic Acid-Induced Acute Colitis in Rats, Res. Pharm. Sci., 3(2), I522.

Mohamed, A.A., 2010, Postulated Protective Role of Curcumin on Indomethacininduced Acute Gastric Mucosal Damage in Adult Albino Rats (Histological and Immunohistochemical Study), Egypt. J. Histol., 33(3), 583-593.

Mizui, T. and Douteuchi, M.,1983. Effect of Polyamines on Acidi Fied EthanolInduced Gastric Lesionsin Rats, Jpn. J. Pharmacol, 33(5), 939-945.

Saputri, F.C., Sari, S.P. and Mun'im, A., 2008, Pengembangan Metode Induksi Tukak Lambung, Majalah Ilmu Kefarmasian, 5(2), 84-90. 